Милијана Ђорђевић

Универзитет у Београду

Филолошки факултет
929 Јанићијевић Ј. , 012 Јанићијевић Ј. doi 10.18485/analiff.2015.27.1.3

\title{
ЖИВОТ И ДЕЛО ПРОФ. ДР ЈАСНЕ (СТОЈКОВ) ЈАНИЋИЈЕВИТ
}

\begin{abstract}
У овом раду ауторка најпре најпре даје кратку биографију проф. др Јанићијевић, са личним реминисценцијама. Затим пружа и потпуну библиографију професоркиних радова.
\end{abstract}

Кључне речи: Јасна Јанићијевић, библиографија, биографија, живот, сећања

Моја прва сећања на нашу колегиницу, професора Филолошког факултета, Семинара за друштвене науке, професорку Јасну Јанићијевић, њен самопрегорни рад и узорни живот датирају још из јануарских дана 1987. године када сам се запослила као асистент-приправник на Филолошком факултету. Сећам се топлог пријема код лепе жене са осмехом на лицу који се није скидао током разговора уз шољицу кафе у продеканској соби. Професорица је тада била продекан за наставу (1985-1987) и пракса је била да се упозна са новим члановима колектива.

Јасна Јанићијевић је рођена у Београду у ратном вихору 12. априла 1943. године. Гимназију и Филозофски факултет (їруйа за енїлески језик и кьижевности и франиуски језик) завршила је у Сарајеву 1965. године. При крају студија у Сарајеву, 1964., уписала се на Филолошки

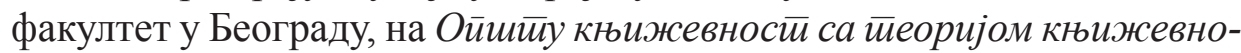
$c \bar{u} u$, где је дипломирала 1968. године. У међувремену, 1967. године, завршила је и постдипломске студије из енглеске књижевности, такође на Филолошком факултету у Београду, под менторством проф. др Виде Марковић. Магистарску тезу радила је из области естетике и теорије књижевности на примеру поетике Џемса Џојса, под насло-

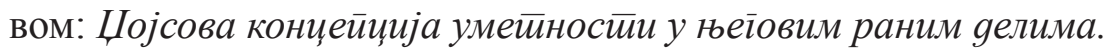

За време постдипломских студија, провела је један семестар у Енглеској на Холовеј колеџу код Лондона, као и на универзитету у 
Авериствиту у Велсу, где је проучавала грађу (литературу) потребну за свој рад о Џемсу Џојсу. Године 1969. била је на студијском боравку у Кембриџу, где је похађала семинар из савремене енглеске књижевности.

У раним радовима бавила се ликовном и позоришном критиком од 1962. до 1963. године. Педагошки рад почиње на Коларчевом народном универзитету где је у периоду октобар 1968. до јануара 1971. године била запослена као професор енглеског језика. Каријеру универзитетског професора почиње јануара 1971. године на Филолошком факултету у Београду, у звању асистента-приправника за предмет $C o$ циологија кулииуре и умейностии код професора Милоша Илића, а након две године (1973) је бирана у звање асистента за исти предмет.

Године 1983. одбранила је докторску дисертацију под насловом: Социолоіија модерне књижевне комуникације - Прилоі иеорији књижевне рецейцие Ђерђа Лукача, чиме је стекла услов за избор у звање доцента у које је изабрана наредне године, 1984. У исто звање реизабрана је 1992. године. За ванредног професора изабрана је 1995. године за предмет Кулииуролоїија, а за редовног професора 2000. године.

Др Јасна Јанићијевић је у више наврата боравила на студијским усавршавањима у иностранству, у Француској (1985) и у САД (19871988, 1995 и 1997). Током боравка у Француској, научно се усавршавала радећи у Националној библиотеци у Паризу. Боравећи школске 1987/88. године у Вашингтону, радила је у Конгресној библиотеци на прикупљању грађе за студије комуникологије. Том приликом одржала је серију предавања о култури на тлу Србије, на Институту Смитсонијан, као и више јавних предавања на Мерилендском универзитету. Боравећи у два наврата $(1995,1997)$, у Калифорнији, Универзитет у Санта Барбари, радила је на припреми своје књиге о комуникацији u кулйури, где је такође држала и више предавања и где се активно ангажовала у међународном пројекту Women Beyond Borders. Tај пројекат, који је потпомогло Републичко Министарство културе Србије, успешно је окончан 1997. у Београду, организацијом изложбе коју је припремила др Јасна Јанићијевић, окупивши дванаест ликовних уметница Србије, чија су дела касније излгана широм света.

Поред општег курса за који је бирана у сва наставничка звања (Социолоіија кулииуре, сада Кулйуролойија), проф. др Јасна - Сека 
(како су је њени најближи звали) бавила се проблемима културе и комуникације, о чему је написала више радова, студија и чланака и држала предавања на факултету, као посебан курс под називом Tеорија информација и комуникација, а истовремено и друге курсеве на

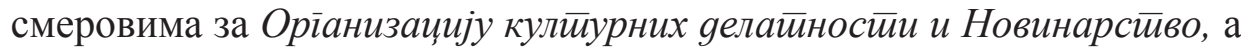
затим и курс из Кулииурне анимације. На овим курсевима предавала је више предмета из културолошких и комуниколошких студија и била руководилац тих студијских група. Такође, у оквиру специјалистичких студија на Филолошком факултету била је руководилац и сииални мен-

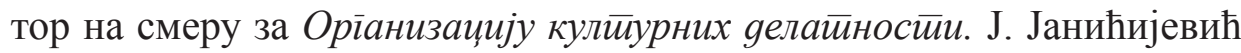
је руководила и учествовала у више комисија за магистарске и докторске дисертације, као и у комисија за изборе.

У пензију одлази септембра 2011. године, а почетком августа 2013. године после тешке, неизлечиве болести, одлази заувек анђелима.

У биографији др Јасне Јанићијевић стоји да је сарађивала у многим значајним стручним часописима на простору бивше Југославије: Наши

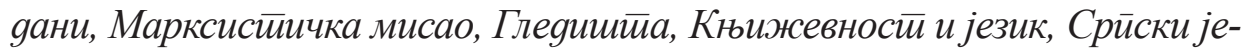
зик, Трећи ироірам, Кюижевне новине, Брайсииво, и многи други...

Током своје професорске каријере на Филолошком факултету др Јасна Јанићијевић је била члан бројних тела, органа и организација унутар своје матичне куће. У једном периоду била је и потпредседник Савета, члан различитих комисија, а у периоду од 1985-1987. била је продекан за наставу и вршилац дужности декана (1987-1988). Све своје обавезе и функције, Ј. Јанићијевић је обављала успешно и савесно, са изразитим смислом за сарадњу са колегама и свим осталим члановима колектива. Поред обавеза на факултету она је била и члан редакције Марксистиччке мисли, председник СИЗ-а културе општине Стари Град (1984-1989), затим йомоћник минисиира за кулииуру Србије (1989-1992). Такође, била је један од иницијатора обнављања рада ча-

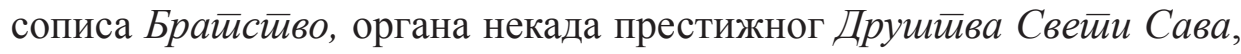
чији је генерални секретар постала. Њен посебан допринос огледа се на плану међународне културне сарадње, заштите споменика културе, као и спасавања споменика српске културне баштине у ратом захваћеним подручјима. Њеном иницијативом и залагањем штампана је и монографија о разрушеним споменицима Српске православне цркве у Хрватској, у рату 1991-1992. године. 


\section{2.}

1. ЈАНИЋИЈЕВИЋ, Јасна

Присно и блиско (уз изложбу тројице загребачких уметника). Наши gани,

Сарајево, март 1962. [Ликовна критика].

2. ЈАНИЋИЈЕВИЋ, Јасна

Без боја без маште (шестоаприлска изложба УЛУБИХА). Наши gани, Сарајево, март 1962. [Ликовна критика].

3. ЈАНИЋИЈЕВИЋ, Јасна

Минијатуре тренутка (уз изложбу Фрање Ликара). Наши gани , Сарајево, април 1962. [Ликовна критика].

4. ЈАНИЋИЈЕВИЋ, Јасна

Незасити дух тражења. (Пољска графика у Сарајеву). Наши gани, Сарајево, април 1962. [Ликовна критика].

5. ЈАНИЋИЈЕВИЋ, Јасна

Прсти земље. (Иван Генералић у уметничком павиљону). Наши gани, Сарајево, мај 1962. [Ликовна критика].

\section{3.}

6. ЈАНИЋИЈЕВИЋ, Јасна

Андора Макса Фриша. Наши яани, Сарајево, фебруар 1963.

[Позоришна критика].

7. ЈАНИЋИЈЕВИЋ, Јасна

Дилеме ликовних уметника. (Поводом изложбе УЛУБИХА). Наши gани, Сарајево, март 1963. [Ликовна критика].

8. ЈАНИЋИЈЕВИЋ, Јасна

Како су се сами насликали. (Изложба аутопортрета). Наши gани, Сарајево, мај 1963. [Ликовна критика].

9. ЈАНИЋИЈЕВИЋ, Јасна

Уз изложбу Воје Димитријевића, Наши gани, Сарајево, мај 1963. [Ликовна критика].

10. ЈАНИЋИЈЕВИЋ, Јасна

Tu Dyca, tu Signore et tu Maestro. (Уз годишњицу Едуарда Манеа), Наши gани, Сарајево, мај 1963. [Ликовна критика].

1967.

11. ЈАНИЋИЈЕВИЋ, Јасна

Џојсова концепција уметности у његовим раним делима, магистарски рад, Филолошки факултет, Београд. 


\section{8.}

12. ЈАНИЋИЈЕВИЋ, Јасна

Ванс Пикард: Голо друштво. [Превод са енглеског језика]. Трећи ирроірам Радио-Београда, емитовано од 8 до 12 јануара (четири наставка), 1968.

\section{9.}

13. ЈАНИЋИЈЕВИЋ, Јасна

Марсел Гране: ТАО. [Превод са енглеског језика]. "Теорије о друштву", "Вук Караџић", Београд, 1969, стр. 1040-1043.

14. ЈАНИЋИЈЕВИЋ, Јасна

Мира Вељић: Children Foster Care in Yugoslavia. [Превод са енглеског језика]. Институт за социјалну политику, Београд, 1969.

1971.

15. ЈАНИЋИЈЕВИЋ, Јасна

Лесли Вајт: Наука о култури. Глеgишӣа, Београд, 1971, год. XII, бр.3. стр. 532-536. [Приказ].

16. ЈАНИЋИЈЕВИЋ, Јасна

Роберт Ескарпит: Социологија књижевности. Глеgишйа, Београд, 1971, год. ХІІ, бр.4. стр. 746-749. [Приказ].

17. ЈАНИЋИЈЕВИЋ, Јасна

Свет чула и општила. Глеgишй $а$, Београд, 1972, год. ХІІІ, бр.3. стр. 527-534. [Осврт].

1973.

18. ЈАНИЋИЈЕВИЋ, Јасна

Серж Дубровски: Зашто нова критика? Глеgишииа, Београд, 1973, год. XIV, бр.1. стр. 115-119. [Приказ].

19. ЈАНИЋИЈЕВИЋ, Јасна

Ратко Божовић: Метаморфозе игре. Глеgишй $а$, Београд, 1973, год. XIV, бр.2. стр. 249-253. [Приказ].

1974.

20. ЈАНИЋИЈЕВИЋ, Јасна

Џојсова концепција уметности одражена у његовим раним делима. Анали филолошкої факулиеейа, Београд, 1974, књ. ХІ, стр. 121-147. [Студија].

21. ЈАНИЋИЈЕВИЋ, Јасна

Абрахам Мол: Кич-уметност среће. Глеgишйа, Београд, 1974, год. XV, бр.4. [Приказ]. 
22. ЈАНИЋИЈЕВИЋ, Јасна

Ренато Пођоло: Теорија авангардне уметности. [Превод са енглеског]. "Нолий", Београд, 1974, стр. 258.

23. ЈАНИЋИЈЕВИЋ, Јасна

Сигмунд Фројд: Фиксирање либида за објекте. "Теорија о gрушииву", стр. 695-699.

24. ЈАНИЋИЈЕВИЋ, Јасна

Иван Павлов: О условним рефлексима. "Теорија о ярушииву", стр. 728-733.

25. ЈАНИЋИЈЕВИЋ, Јасна

Курт Левин: О валенцији. "Теорија о gрушииву", стр. 756-760.

26. ЈАНИЋИЈЕВИЋ, Јасна

Сигмунд Фројд: Завршена и незавршена анализа. "Теорија o gрушиевву", стр. 856-868.

27. ЈАНИЋИЈЕВИЋ, Јасна

Фредерик М. Трешер: Друштвени системи и ганг. "Теорија о ярушишву", стр. 881-886.

28. ЈАНИЋИЈЕВИЋ, Јасна

В. И. Томас и Ф. Знањецки: Три типа личности. "Теорија о gрушииву", стр. 886-892.

29. ЈАНИЋИЈЕВИЋ, Јасна

Бронислав Малиновски: О друштвеним улогама религије."Теорија о ярушитву", стр. 1034-1038.

30. ЈАНИЋИЈЕВИЋ, Јасна

В. Робертсон Смит: О жртвовању. "Теорија о друиииву", стр. 1038-1040.

31. ЈАНИЋИЈЕВИЋ, Јасна

Сигмунд Фројд: О психологији и историји. "Теорија о gрушишву", стр. 1197-1202.

32. ЈАНИЋИЈЕВИЋ, Јасна

Макс Вебер: Рутинизација харизме. "Теорија о gрушииву", стр. 1229-1235.

1975.

33. ЈАНИЋИЈЕВИЋ, Јасна

Милан Ранковић: Култура и некултура. Глеgишй $а$, Београд, 1975, год. XVI, бр.2. [Осврт].

34. ЈАНИЋИЈЕВИЋ, Јасна

Милош Немањић: Културне потребе. Глеgишйа, Београд, 1975, год. XVI, бр.3. [Осврт].

35. ЈАНИЋИЈЕВИЋ, Јасна

Иванка Ковачевић: Fact into Fiction. Глеgишӣа, Београд, 1975, год. XVI, бр. 12. стр. 376-384. [Приказ]. 


\section{9.}

36. ЈАНИЋИЈЕВИЋ, Јасна

Радикализам и статус социјалне драме, Кюиюсевне новине, Београд, 12. мај.

\section{2.}

37. ЈАНИЋИЈЕВИЋ, Јасна

Социолошки лексикон, (одреднице: боемство, декаденција, културно поље, некултура, противкултура), Савремена ауминисиирација, Београд.

38. ЈАНИЋИЈЕВИЋ, Јасна

Лукачева феноменолошка социологија уметничке комуникације, Анали филолошкої факулиеейа, Београд, 1982, стр. 295-335.

\section{3.}

39. ЈАНИЋИЈЕВИЋ, Јасна

Социологија модерне књижевне комуникације - Прилог теорији књижевне рецепције Ђерђа Лукача, докторска дисертација, Филолошки факултет. Београд

\section{4.}

40. ЈАНИЋИЈЕВИЋ, Јасна

Марксистичка теорија књижевне рецепције, Марксистиччка мисао, бр.4. Београд, 1984. стр. 86-107.

\section{6.}

41. ЈАНИЋИЈЕВИЋ, Јасна

Схема и форме (Прилог теорији књижевне рецепције Ђерђа Лукача), Нова къиі̄а, Београд, 1986, стр. 256.

\section{8.}

42. ЈАНИЋИЈЕВИЋ, Јасна

Belgrade, White at the Crossroads od East and West, Smithsonian Institute, Washington D.C., The Smithsonian associate, vol. 16. No. 7, March 1988, p. 24; Vol. 16. No. 8. April, 1988. pp. 29; Vol. 17, No. 9, May 1988, р. 25 (циклус предавања).

43. ЈАНИЋИЈЕВИЋ, Јасна

Multiculturalism and Cultural Heritage in Yugoslavia, Maryland University, (интерна публикација), мај 1988, pp. 1-7. 
44. ЈАНИЋИЈЕВИЋ, Јасна

Cultural Infuluences and Tradition in Yugoslavia, Дубровник (интерна публикација), Међународни универзитетски центар, јуни 1988, стр. 1-15.

45. ЈАНИЋИЈЕВИЋ, Јасна

Одговорност једног интелектуалца у култури терора (Noam Chomsky, The Culture of Terrorism), Марксистиччка мисао, бр. 6. Београд, 1988, стр. 333-358

\section{0.}

46. ЈАНИЋИЈЕВИЋ, Јасна

Port of Livorno and the Ragusan Seamen During the Second Half of the XVIII Century-Cultural and Trade Relations, "Genova - Mediterraneo Atlantico nell eta moderna", Atti del Congresso Internationale di Studi Storici.. Genova, 1990, pp. 39-61.

\section{1.}

\section{7. ЈАНИЋИЈЕВИЋ, Јасна}

Мирослављево јеванђеље, заштита културне баштине, саопштење на Међународној научној конференцији Словени и разноликосй. "Фонg

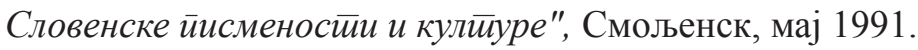

48. ЈАНИЋИЈЕВИЋ, Јасна

Contemporary Yugoslav Culture, Conference data. Third Eye Centre Glasgow, 1991.

49. ЈАНИЋИЈЕВИЋ, Јасна

Danube-the River of Cultural Cooperation, Conference of the Danube Countries, Cultural Programme, Sofia, април, 1991.

50. ЈАНИЋИЈЕВИЋ, Јасна

Le role des regions et de colectivites locales dans le processus de development de la creation d' images. Jornees Professionelles du Cinema at de 1' Audiovisuel, Montpellier, март, 1991.

51. ЈАНИЋИЈЕВИЋ, Јасна

Источна Европа - промене и културна политика, Вукова заяужбина, бр.13, Београд, фебруар 1991.

52. ЈАНИЋИЈЕВИЋ, Јасна

Источна Европа - нови духовни идентитет, "Полишика", (културни додатак), Београд, 2. март 1991.

53. ЈАНИЋИЈЕВИЋ, Јасна

За балетску уметност у Србији, "Полиишика", (културни додатак), Београд, 13. април 1991. 
1992.

54. ЈАНИЋИЈЕВИЋ, Јасна

Почетак Колумбове године у родној Ђенови, "Полиииика", (културни додатак), Београд, 8. април 1992.

\section{3.}

55. ЈАНИЋИЈЕВИЋ, Јасна

Рецепција традиционалног и модерног поетског исказа на узорку студената Београдског универзитета (са др Љ. Жиропађом), 23. Међунарояни сасиианак Слависйа у Вукове дане (тезе и резимеа), Београдм 1993.

1994.

56. ЈАНИЋИЈЕВИЋ, Јасна

Путовање до последњег круга, предговор за књигу Ђ. Тоски Марацини Висконти, Путовање у лудило једног рата, Београд, 1994, стр. 5-8.

57. ЈАНИЋИЈЕВИЋ, Јасна

Теоријски и естетски модел рецепције (са мр Зорицом Бобић), 24. Међунарояни састианак Славистиа у Вукове ане (резимеа), Београд, 1994.

58. ЈАНИЋИЈЕВИЋ, Јасна

Култура и комуникација - приступи, 24. Међународни састианак

Славистиа у Вукове яане (резимеа), Београд, 1994.

59. ЈАНИЋИЈЕВИЋ, Јасна

Алекс Драгнић, Никола Пашић, Србија и Јуіославија (превод са С.

Граховац), Београд, 1994, стр. 275.

1995.

60. ЈАНИЋИЈЕВИЋ, Јасна

An Analysis of Aesthetic Orientation (са С. Петровићем, Љ.Жиропађом и др.), IV European Congress of Psychology, јули 1995, Атина

(објављен резиме).

1996.

61 JANICIJEVIC, Jasna

Reception of Columbus' Discovery in the Ragusian Poetry of the XVI and XVII Century, "Genova, Mediterraneo, Atlantico nell'eta moderna", Atti

del V congress internacionale de studi storici, Genova 1996, str. 213 - 234.

62. ЈАНИЋИЈЕВИЋ, Јасна

Рецепција уметности, (коаутор са Сретеном Петровићем, Мирјаном

Хофман и др.), Филолошки факултет, Београд, 1996, стр. 239-303. 
63. ЈАНИЋИЈЕВИЋ, Јасна

"Година културе", (Зборник), Београд, 1996, стр. 14-17.

1998.

64. ЈАНИЋИЈЕВИЋ, Јасна

Питер Геј, Вајмарска кулииура (превод), Геойоейика, Београд, 1998. стр. 256.

1999.

65. ЈАНИЋИЈЕВИЋ, Јасна

О љубави, (љубовағе Анђелке Милојковић), Кюижевносӣ, Београд, 1999, стр. 486-490.

66. ЈАНИЋИЈЕВИЋ, Јасна

Од књиге до компјутера, "Полиииика", (културни додатак), Београд, 24. октобар, 1999.

2000.

67. ЈАНИЋИЈЕВИЋ, Јасна

Комуникација и кулйура, Издавачка књижарница Зорана Стојановића, Нови Сад, 2000, стр. 354.

2005.

68. ЈАНИЋИЈЕВИЋ, Јасна

Мисија културе, Политика, 13. октобар 2005, стр. 6.

2007.

69. ЈАНИЋИЈЕВИЋ, Јасна

Комуникачија и кулииура, Издавачка књижарница Зорана Стојановића, Нови Сад, 2000, друго издање, стр. 354.

2010.

70. ЈАНИЋИЈЕВИЋ, Јасна

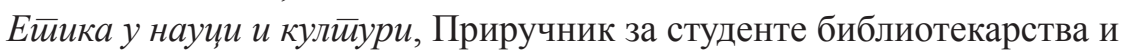
информатике, Филолошки факултет, Београд, 2010, стр. 179.

2011.

71. ЈАНИЋИЈЕВИЋ, Јасна

Духовна веза између два ренесансна великана: Пико дела Миранgола и њейов йосреяни уйииај на Франсоа Раблеа, Анали филолошког факултета, свеска посвећена Ратку Нешковићу, 23 свеска I, Београд, 2011, стр. 27-29. ИССН 0522-8468, 


\section{Литература}

Анали Филолошкої факулиетейа, свеска бр. 13, Београд, 1979. Реферат за избор у редовног професора, Филолошки факултет, Београд, 2000.

Milijana Đorđević

\section{Summary \\ LIFE AND WORK OF PROFESSOR JASNA (STOJKOV) JANIĆIJEVIĆ, PhD}

In this paper, the author first provides a brief biography of Professor Jasna Janićijević, $\mathrm{PhD}$, together with personal reminiscences. Then a complete bibliography of professor's works is given.

Key words: Jasna Janićijević, bibliography, biography, life, memories 